Original article

\title{
DNA damage protecting and free radical scavenging properties of Terminalia arjuna bark in PC-12 cells and plasmid DNA
}

\author{
G. Phani Kumar ${ }^{\text {a, }}$, K. Navya ${ }^{a}$, E.M. Ramya ${ }^{a}$, M. Venkataramana ${ }^{\text {b }}$, T. Anand ${ }^{\text {c }}$, K.R. Anilakumar ${ }^{\text {a }}$ \\ ${ }^{a}$ Applied Nutrition Division, Defence Food Research Laboratory (DRDO), Mysore 570011, India \\ ${ }^{\mathrm{b}}$ Microbiology Division, Defence Food Research Laboratory (DRDO), Mysore 570011, India \\ ${ }^{\mathrm{c}}$ Biochemistry and Nanoscience Division, Defence Food Research Laboratory (DRDO), Mysore 570011, India
}

\section{A R T I C L E I N F O}

Article history:

Received 9 March 2013

Accepted 18 April 2013

Available online 25 April 2013

\section{Keywords:}

DNA damage protection

PC -12 cells

Antioxidant activity

Free radical scavenging activity

Terminalia arjuna

\begin{abstract}
A B S T R A C T
Objective: Terminalia arjuna is commonly known as Arjuna and widely used as cardioprotective agent in Indian traditional medicine. The present study was undertaken to evaluate the protective effect of ethanolic extract of T. arjuna bark (TAA) and its fractions, including dichloromethane (TAD), ethyl acetate (TAE), butanol (TAB) and water (TAW) against free radicals, protein oxidation and DNA damage. Methods: Protective effect of arjuna bark against $\mathrm{H}_{2} \mathrm{O}_{2}$ induced DNA damage on pBR322 plasmid and rat adrenal PC-12 cells was analyzed by DNA strand breakage assay and single cell gel electrophoresis (Comet assay) respectively. AAPH induced protein oxidation was analyzed with SDS-PAGE. In vitro antioxidant activities were carried out by spectrophotometric methods to asses free radical scavenging activities, such as DPPH, hydroxyl, ABTS, nitric oxide, metal chelation, FRAP and reducing power.

Results: The ethanolic extract and its fractions of arjuna bark effectively protected $\mathrm{H}_{2} \mathrm{O}_{2}$ induced DNA damage and AAPH induced protein oxidation in the following manner: TAE $>$ TAB $>$ TAA $>$ TAD $>$ TAW. The maximum inhibition of DPPH, hydroxyl, ABTS, nitric oxide radicals and metal chelation was observed in TAE fraction ( $\mathrm{IC}_{50}$ values: $270 \pm 2 \mu \mathrm{g} / \mathrm{ml}, 175 \pm 11 \mu \mathrm{g} / \mathrm{ml}, 25 \pm 1.2 \mu \mathrm{g} / \mathrm{ml}, 405 \pm 9 \mu \mathrm{g} / \mathrm{ml}, 310 \pm 11 \mu \mathrm{g}$ / $\mathrm{ml}, 82 \pm 4 \mu \mathrm{g} / \mathrm{ml}$, respectively).

Conclusion: In the present study we report that arjuna bark extracts ameliorate various impairments associated with DNA damage and free radical formation.

Copyright $\odot$ 2013, SciBiolMed.Org and Phcog.Net, Published by Reed Elsevier India Pvt. Ltd. All rights
\end{abstract} reserved.

\section{Introduction}

Terminalia arjuna (Roxb.) Wight and Arn, belonging to the family Combretaceae, commonly known as "Arjuna". It is an important ayurvedic medicinal plant to treat hypertension, ischemic heart diseases and a well known cardioprotective agent since long. ${ }^{1}$ T. arjuna bark known for its ethnomedicinal significance ${ }^{2}$ and is frequently used in cardiovascular disorders such as heart failure, coronary artery diseases, and to reduce hypercholesterolemia. ${ }^{3}$ The bark is also prescribed in biliousness and sores and as an antidote to poison, and it is believed to have an ability to cure hepatic, congenital, ulcers, blood diseases, anemia, asthma and viral diseases. ${ }^{4}$ The extract of the bark has been also reported for its activities like antimicrobial, antimutagenic and anthelmintic. ${ }^{5}$ In addition, the arjuna bark has also evaluated as for its antifertility and anti-HIV properties.

\footnotetext{
* Corresponding author. Tel.: +91 8212579485.

E-mail address: phani_dfrl@rediffmail.com (G. Phani Kumar).
}

Several researchers worked on phytochemical investigation of the T. arjuna and evaluated a variety of phytochemicals from different parts of the plant. Few triterpenoids were isolated from the bark of the T. arjuna are arjunin, arjunic acid, arjunolic acid, arjungenin, terminic acid. ${ }^{6-8}$ Some of the glycosides identified from the bark are: arjunetin, arjunoside I, arjunoside II, arjunaphthanoloside, terminoside A. ${ }^{6-9}$ Flavonoids detected from its bark are, arjunolone, bicalein, flavones, kempferol, quercetin, and pelorgonidin. ${ }^{10}$ Besides, several compounds related to tannins have been isolated from the bark are punicallin, castalagin, casuariin, pyrocatechols, terchebulin, punicalagin, terflavin $\mathrm{C}$ and casuarinin. ${ }^{11}$ The bark is also rich in essential mineral such as calcium (3133 $\mu \mathrm{g} / \mathrm{g})$, magnesium $(4000 \mu \mathrm{g} / \mathrm{g})$, copper $(19 \mu \mathrm{g} / \mathrm{g})$, zinc $(119 \mu \mathrm{g} /$ g) and silica. ${ }^{12}$

Screening medicinal plants for novel bioactive compounds are the sole remedy since, plant based drugs are biodegradable, safe and have fewer side effects. Thus, the therapeutic potential of the herbs opens up new vista in the future pharmacological research of herbal drug development. Besides, in the last few years, interest in 
the antioxidant activity of the plant extracts has increased tremendously which is very important due to the fact that hyperphysiological load of oxidants can make an imbalance state between free radicals and antioxidants in the system. This difference between oxidants and antioxidants leads to oxidative stress, which is the root cause of several disorders like aging, stroke, atherosclerosis, cancer, diabetes and other neurological disorders such as anxiety, depression, Parkinsonism and Alzheimer's diseases. In view of the above facts, the present study designed to evaluate the protective activity against $\mathrm{H}_{2} \mathrm{O}_{2}$ induced DNA damage, protein oxidation and antioxidant potential of different extracts of T. arjuna.

\section{Materials and methods}

\subsection{Plant material and extraction}

T. arjuna bark samples were collected from Mysore, India and properly authenticated by the Department of Botany, University of Mysore, Mysore. It was defatted with the diethyl ether for $24 \mathrm{~h}$ and the same materials were extracted with ethyl alcohol for $72 \mathrm{~h}$ in soxhlet apparatus. The extract was filtered and dried under reduced pressure. The alcoholic extract was further fractionated with several solvents. The extraction procedure and their yield are explained in Fig. 1. Then we obtained total five different extracts viz., alcoholic extract (TAA), dichloromethane extract (TAD), ethyl acetate extract (TAE), butanol extract (TAB), and water extract (TAW).

\subsection{DNA damage protection assay}

\subsubsection{Determination of oxidative plasmid DNA strand breakage}

Conversion of plasmid DNA from super coiled form to open circular and further linear form is an indication of DNA damage. Plasmid DNA protection assay was performed by using pBR322 plasmid DNA as described by Lee et al. ${ }^{13}$ Briefly, $10 \mu$ l of different fractions of arjuna extract in different concentrations separately (50-200 $\mu \mathrm{g} / \mathrm{ml}$, respectively) and plasmid DNA (0.5 $\mu \mathrm{g})$ were incubated at $37{ }^{\circ} \mathrm{C}$, followed by UV exposure for $20 \mathrm{~min}$ and addition of $10 \mathrm{mM} \mathrm{H}_{2} \mathrm{O}_{2}$. The final volume was made up to $20 \mu \mathrm{l}$ and

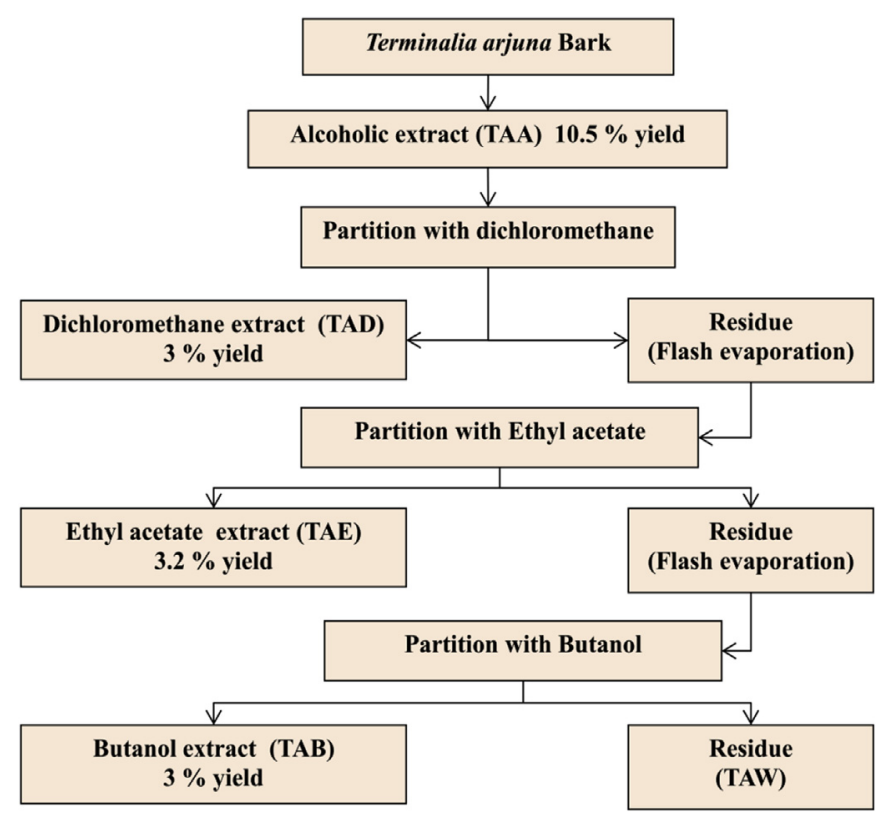

Fig. 1. Sequential extraction of Terminalia arjuna bark. electrophoresed on 1\% agarose gel. Easy win 32 software (Herolab, Germany) was used to analyze band intensities.

\subsubsection{Single cell gel electrophoresis (Comet assay)}

Alkaline comet assay ${ }^{14}$ was performed to measuring the DNA damage and evaluate the apoptosis induced by $\mathrm{H}_{2} \mathrm{O}_{2}$. Rat adrenal PC-12 cell line was obtained from National centre for cell science (NCCS), Pune, India. To examine possible toxic effects of $\mathrm{H}_{2} \mathrm{O}_{2}$, the control cells were treated with $\mathrm{H}_{2} \mathrm{O}_{2}$ at a concentration of $100 \mu \mathrm{M}$ for $24 \mathrm{~h}$, and different extracts of T. arjuna viz., TAA, TAD, TAE and TAW at a concentration of $100 \mu \mathrm{g} / \mathrm{ml}$ for $24 \mathrm{~h}$. Similarly, after treatments, the comet slides were prepared with $1 \mathrm{ml}$ aliquots containing $1 \times 10^{5}$ harvested cells. The photographs were taken with fluorescence microscope (Olympus, Japan) equipped with digital camera. The tail length was measured with the help of Image Pro ${ }^{\circledR}$ plus software and expressed as percent inhibition of tail length.

\subsection{Determination of protein oxidation}

Oxidation of protein was assayed by Kwon et $\mathrm{al}^{15}$ with slight modifications. Oxidation of BSA $(5 \mu \mathrm{g})$ in phosphate buffer was initiated by $20 \mathrm{mM} \mathrm{AAPH}$ and inhibited by different extracts of T. arjuna $(100 \mu \mathrm{g} / \mathrm{ml})$. After incubation for $2 \mathrm{~h}$ at $37^{\circ} \mathrm{C}, 0.02 \%$ BHT was added to prevent the formation of further peroxyl radical. The samples were then analyzed with normal SDS-PAGE.

\subsection{Quantification of total polyphenols and flavonoids}

Total polyphenols were determined by the Folin-Ciocalteu procedure. ${ }^{16}$ The absorbance of blue-colored mixtures recorded after $40 \mathrm{~min}$ at $725 \mathrm{~nm}$ against blank. The amount of total polyphenols was calculated from the calibration curve of gallic acid standard solutions and expressed as $\mathrm{mg} / \mathrm{g}$ GAE of dry extract. The quantification of flavonoids were measured as described by Ordon et al. ${ }^{17}$ Briefly, $0.5 \mathrm{ml}$ of $\mathrm{Al}_{2} \mathrm{Cl}_{3}$ (2\%) ethanolic solution was added to the equal amount of sample. The absorbance was measured at $420 \mathrm{~nm}$ after incubation for $1 \mathrm{~h}$. Flavonoid concentration of the extract was expressed as $\mathrm{mg} / \mathrm{g}$ equivalent of rutin.

\subsection{Determination of in vitro antioxidant activities}

\subsubsection{DPPH radical scavenging activity}

The free radical scavenging activity of different extracts of arjuna bark were determined in vitro by DPPH (1, 1 diphenyl 2, picryl hydrazyl) assay. ${ }^{18} \mathrm{DPPH}$ in methanol $(0.1 \mathrm{mM})$ was prepared and $3.0 \mathrm{ml}$ of this solution was added to $40 \mu \mathrm{l}$ of extract (different concentration of various fractions of arjuna extracts). The absorbance of incubated samples was measured at $515 \mathrm{~nm}$ after incubation for $30 \mathrm{~min}$ at room temperature. Percent inhibition was calculated as follows: DPPH Scavenged $(\%)=[$ A cont - A sample $] / A$ cont $\times 100$, where $A$ cont is the absorbance of the control and $A$ sample is the absorbance of the arjuna fractions.

\subsubsection{Hydroxyl radical scavenging activity}

The hydroxyl radical scavenging activity was analyzed by Halliwell and Gutteridge method with few modifications. ${ }^{19}$ The reaction was initiated by the addition of EDTA $(0.1 \mathrm{ml} ; 1 \mathrm{Mm}), \mathrm{FeCl}_{3}$ $(0.01 \mathrm{ml} ; 10 \mathrm{mM}), \mathrm{H}_{2} \mathrm{O}_{2}(0.1 \mathrm{ml} ; 10 \mathrm{mM})$, deoxyribose $(0.36 \mathrm{ml}$; $10 \mathrm{mM})$, phosphate buffer $(0.33 \mathrm{ml} ; 50 \mathrm{mM}, \mathrm{pH} 7.4)$, ascorbic acid $(0.1 \mathrm{ml})$ and $1.0 \mathrm{ml}$ of arjuna extract $(50-300 \mu \mathrm{g} / \mathrm{ml})$ separately for each fraction. The sample mixture was incubated at $37^{\circ} \mathrm{C}$ for $1 \mathrm{~h}$ and followed by addition of equal amounts of trichloroacetic acid (10\%) and thiobarbituric acid (0.05\%) to develop the pink chromogen, which was measured at $532 \mathrm{~nm}$ and the activity of the 


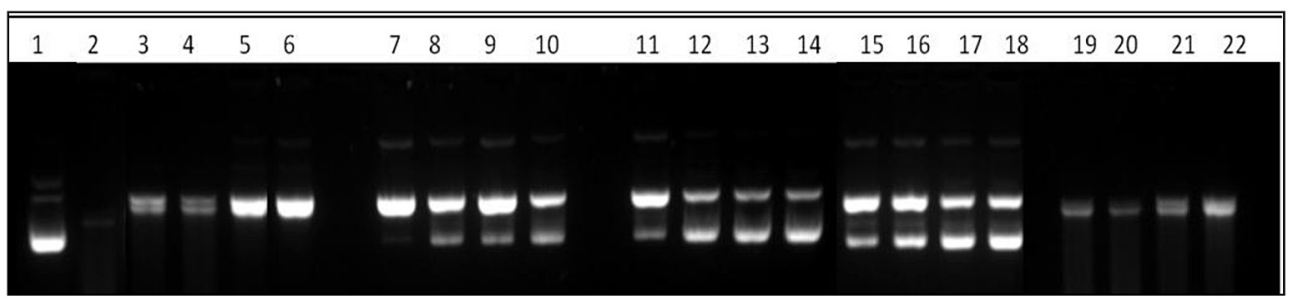

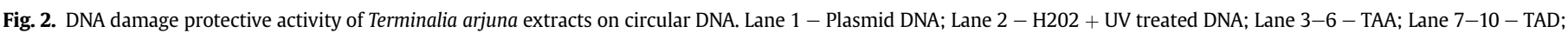
Lane 11-14 - TAE; Lane 15-18 - TAB; Lane 19-22 - TAW. Four treatments were used for each extract i.e. $0.2,0.4,0.6$ \& $0.8 \mathrm{mg} / \mathrm{ml}$ respectively.

extract was reported as the percentage of inhibition of deoxyribose degradation and was calculated according to the following equation: Percent $\mathrm{OH}$ radical scavenged $=[\mathrm{A}$ cont $-\mathrm{A}$ sample $] / \mathrm{A}$ cont $\times 100$, where $A$ cont is the absorbance of the control and $A$ sample is the absorbance of the arjuna fractions.

\subsubsection{ABTS radical scavenging activity}

The ABTS radical scavenging activity $\left[2,2^{\prime}\right.$-azinobis (3ethylbenzothiazoline-6-sulfonic acid) radical] was performed by Re et al. ${ }^{20}$ The working reagent was prepared by mixing of $7 \mathrm{mM}$ ABTS and $2.4 \mathrm{mM}$ potassium per sulfate in equal quantities and then incubated for $12 \mathrm{~h}$ at room temperature in dark. For the above working reagent added different concentrations of arjuna extracts (different fractions separately) and then absorbance was measured at $734 \mathrm{~nm} \%$ ABTS scavenging activity = [A cont $-\mathrm{A}$ sample]/A cont $\times 100$, where $A$ cont is the absorbance of the control and $A$ sample is the absorbance of the arjuna fractions.

\subsubsection{Metal chelating activity}

Metal chelating activity was observed with the percentage inhibition of ferrozine- $\mathrm{Fe}^{2+}$ complex formation. ${ }^{21}$ Briefly, the extract (25-100 $\mu \mathrm{g} / \mathrm{ml}$, different fractions separately) was added to a solution of $2 \mathrm{mM} \mathrm{FeCl}_{2}(0.05 \mathrm{ml})$. The reaction was initiated by the addition of $5 \mathrm{mM}$ Ferrozine $(0.2 \mathrm{ml})$ and then allowed to shake for $10 \mathrm{~min}$ at room temperature. Further absorbance was measured at $562 \mathrm{~nm}$ and inhibition of Ferrozine $-\mathrm{Fe}^{2+}$ complex formation was measured as: $\%$ inhibition $=[A$ cont $-A$ sample $] / A$ cont $\times 100$, where A cont is the absorbance of the control and A sample is the absorbance of the arjuna fractions.

\subsubsection{Total antioxidant activity (FRAP assay)}

Ferric reducing antioxidant property of arjuna fractions were determined by Benzie and Strain ${ }^{22}$ with some modifications.
Briefly, a mixture of $25 \mathrm{ml}$ acetate buffer ( $300 \mathrm{mM}$; pH 3.6), $2.5 \mathrm{ml}$ TPTZ (2, 4, 6-tripyridyl-s-triazine; $10 \mathrm{mM}$ ) in $\mathrm{HCl}$ (40 mM), $2.5 \mathrm{ml}$ $\mathrm{FeCl}_{3} \cdot 6 \mathrm{H}_{2} \mathrm{O}(20 \mathrm{mM})$ and arjuna extract $(150 \mu \mathrm{l}$, different fraction separately). The mixture was then allowed to react with $2850 \mu$ of the FRAP solution for $30 \mathrm{~min}$ in dark and then measured at $593 \mathrm{~nm}$ for the colored product of ferrous tripyridyltriazine complex.

\subsubsection{Nitric oxide scavenging activity}

Nitric oxide scavenging activity was measured by Griess reagent. $^{23}$ Briefly, sodium nitroprusside (10 $\mathrm{mM}$ in phosphatebuffered saline) was mixed with arjuna extracts (different fractions separately) and incubated for $150 \mathrm{~min}$ at room temperature. Further, Griess reagent was added to the sample mixture and absorbance was measured at $546 \mathrm{~nm} \%$ inhibition $=[$ A cont $-\mathrm{A}$ sample]/A cont $\times 100$, where $A$ cont is the absorbance of the control and A sample is the absorbance of the arjuna fractions.

\subsubsection{Reducing power assay}

Different concentrations of arjuna extracts were added with $2.5 \mathrm{ml}$ of phosphate buffer $(0.2 \mathrm{M}, \mathrm{pH} 6.6), 2.5 \mathrm{ml}$ of potassium ferricyanide (1\%). To the above mixture, $2.5 \mathrm{ml}$ of trichloroacetic acid $(10 \%)$ was added after $30 \mathrm{~min}$ incubation at $50{ }^{\circ} \mathrm{C}$ and centrifuged. Collected supernatant and mixed with equal amount of distilled water with $0.5 \mathrm{ml} \mathrm{FeCl}_{3}(0.1 \%)$ and the absorbance was measured at $700 \mathrm{~nm} .^{24}$ The increased absorbance of the reaction mixture was considered as reducing power.

\subsection{Statistical analysis}

Results were expressed as mean value \pm Standard deviation $(n=4)$. Linear regression analysis was conducted to find out the correlation coefficient. Statistical significance was evaluated employing $t$-test and $P<0.05$ was considered to be significant.

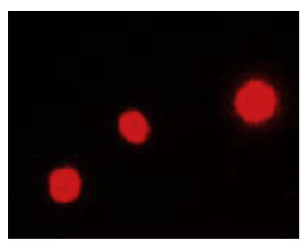

Control

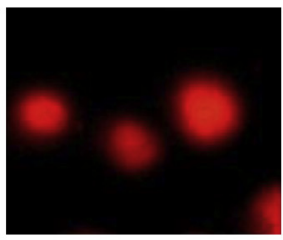

TAE

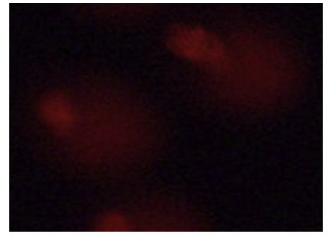

$\mathrm{H}_{2} \mathrm{O}_{2}$

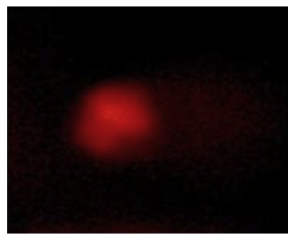

TAB

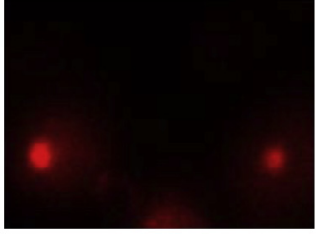

TAA

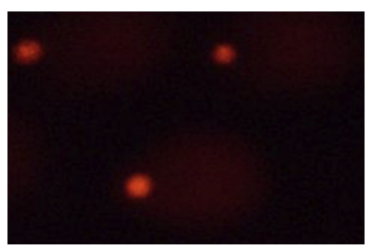

TAW

Fig. 3. DNA damage protection assay by single cell gel electrophoresis (SCGE). 


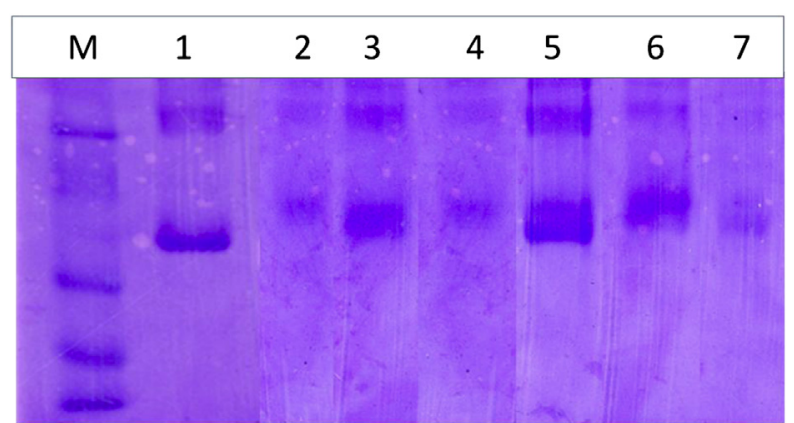

Fig. 4. The inhibitory activity of protein oxidations. Lane M - Marker (100 kD); Lane 1 - BSA (Positive control); Lane 2 - AAPH treatment (negative control); Lane 3 - TAA; Lane 4 - TAD; Lane 5 - TAE; Lane 6 - TAB; Lane 7 - TAW.

\section{Results}

\subsection{Effect of T. arjuna on super coiled DNA damage protection}

The super coiled form of plasmid DNA pBR322 was the predominant band when the control DNA was run on an agarose gel (Fig. 2). T. arjuna extracts dose dependently inhibited hydrogen peroxide/UV induced DNA cleavage in the following manner: TAE $>$ TAB $>$ TAD $>$ TAA $>$ TAW (Fig. 2; lane 11-14, 15-18, 7-10, 26 and $19-22$, respectively).

\subsection{Effect of T. arjuna on PC-12 cell DNA damage protection}

The supplementation of $T$. arjuna extracts with $\mathrm{H}_{2} \mathrm{O}_{2}$ to rat adrenal PC-12 cells revealed an observable enhancement in \% Head DNA. The median tail moment of the control cell line treated with $\mathrm{H}_{2} \mathrm{O}_{2}$ alone (without extract) was assigned an arbitrary value of 1.0 in order to compare among the different fractions of arjuna extract treatments. The comet results showed the damage protective activity of arjuna extracts in the same way as plasmid DNA protection i.e. $\mathrm{TAE}>\mathrm{TAB}>\mathrm{TAD}>\mathrm{TAA}>\mathrm{TAW}$ (Fig. 3 ).

\subsection{Inhibition of protein oxidation by T. arjuna}

Results are presented in Fig. 4 showed that the BSA was completely degraded by $20 \mathrm{mM}$ AAPH in the control as studied by SDS-PAGE electrophoresis. Pre-treatment of $T$. arjuna extracts showed protective effect significantly by restoring the band intensity upto $90 \%$ by TAE when compared with control. The inhibition activity protein oxidation by the different extracts as follows: TAE $>$ TAB $>$ TAA $>$ TAD $>$ TAW.

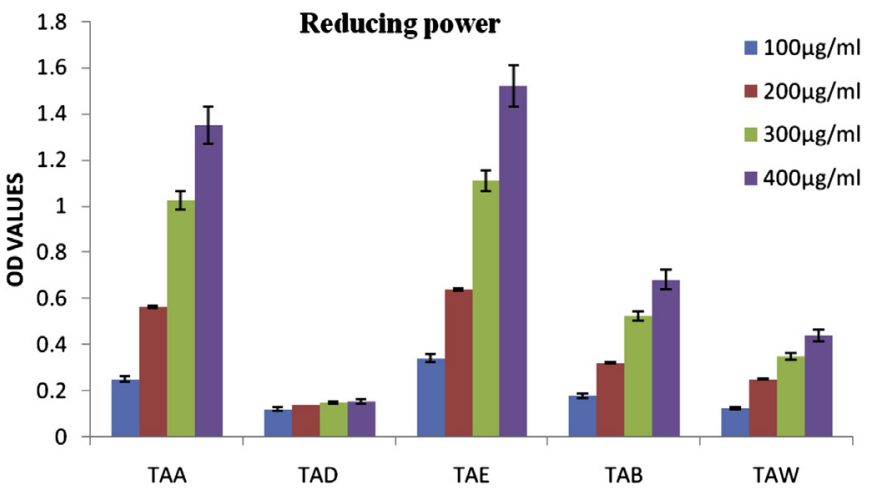

Fig. 5. Reducing power assay of Terminalia arjuna extracts.

\subsection{Quantification of polyphenols and flavonoids}

Different extracts of arjuna bark were reported in a vast range of polyphenols from $50 \pm 6 \mathrm{mg} / \mathrm{g}$ to $430 \pm 18 \mathrm{mg} / \mathrm{g}$ GAE and the flavonoids were $4.1 \pm 0.1-21 \pm 0.2 \mathrm{mg} / \mathrm{g}$ RE. The results of phenolics and flavonoids of arjuna bark extracts/fractions were given in Table 1.

\subsection{Antioxidant scavenging activity of T. arjuna}

The antioxidant activities of all extracts were increased with an increasing concentration of the extract. The $\mathrm{IC}_{50}$ values of $\mathrm{DPPH}$, ABTS, hydroxyl and nitric oxide radical scavenging activities, metal chelating activity were showed higher activity with TAE (Table 1). The FRAP assay, which is expressed in units of $\mu \mathrm{mol} F e($ II)/g were given in Table 1 . The reducing power of different extracts of $T$. arjuna bark are summarized in (Fig. 5).

\section{Discussion}

Defence mechanism against oxidants, toxins, pathogens and other causative agents of stress are balanced by the body with the help of different antioxidant mechanisms like, protein expression, gene expression, DNA repair, stress enzymes like SOD, CAT, GPx etc. ${ }^{25}$ DNA damage is one of the biological marker to see the antioxidant capacity of any medicinal plant. ${ }^{26}$ The present study confirmed that TAE and TAA were able to protect PC-12 cells in the comet assay and pBR322 plasmid DNA against $\mathrm{H}_{2} \mathrm{O}_{2}$ induced DNA damage. Previous reports of Sivalokanathan ${ }^{27}$ support the present results and further extending the application of $T$. arjuna bark extract against DNA damage of human hepatoma cell line HepG2 along with PC-12 cells. In the present study T. arjuna extracts (TAA, TAE and TAB) showed protection against AAPH induced protein

Table 1

Antioxidant activity and quantification of polyphenol, and flavonoid contents.

\begin{tabular}{|c|c|c|c|c|c|}
\hline Parameter & TAA & TAD & TAE & $\mathrm{TAB}$ & TAW \\
\hline DPPH radical scavenging activity ${ }^{\mathrm{a}}$ & $283 \pm 15$ & $>500$ & $270 \pm 12$ & $363 \pm 18$ & $>500$ \\
\hline Hydroxyl radical scavenging activity ${ }^{a}$ & $185 \pm 9$ & $>500$ & $175 \pm 11$ & $441 \pm 21$ & $>500$ \\
\hline ABTS radical scavenging activity ${ }^{\mathrm{a}}$ & $31 \pm 2$ & $212 \pm 10$ & $25 \pm 1.2$ & $125 \pm 8$ & $251 \pm 14$ \\
\hline Metal chelating activity ${ }^{\mathrm{a}}$ & $421 \pm 11$ & $>500$ & $405 \pm 15$ & $475 \pm 29$ & $>500$ \\
\hline FRAP assay ${ }^{\mathrm{b}}$ & $425 \pm 25$ & $>500$ & $310 \pm 15$ & $365 \pm 11$ & $465 \pm 21$ \\
\hline Nitric oxide scavenging activity ${ }^{a}$ & $110 \pm 4$ & $99 \pm 7$ & $82 \pm 4$ & $85 \pm 5$ & $121 \pm 4$ \\
\hline Poly phenols ${ }^{c}$ & $430 \pm 18$ & $50 \pm 6$ & $380 \pm 13$ & $101 \pm 5$ & $190 \pm 8$ \\
\hline Flavonoids ${ }^{\mathrm{d}}$ & $11 \pm 0.6$ & $4.1 \pm 0.1$ & $21 \pm 0.2$ & $5.6 \pm 0.4$ & $1.5 \pm 0.05$ \\
\hline
\end{tabular}

\footnotetext{
${ }^{\text {a }}$ Expressed in $\mathrm{IC}_{50}$ values in $\mu \mathrm{g} / \mathrm{ml}$.

b Expressed in units of $\mu \mathrm{mol} \mathrm{Fe} \mathrm{(II)/g.}$

c Expressed in units of $\mathrm{mg} / \mathrm{g}$ of gallic acid equivalents.

d Expressed in units of $\mathrm{mg} / \mathrm{g}$ of rutin equivalents.
} 
oxidation. These results are encouraging and also may have positive role in inhibiting several stress/toxic induced protein oxidation.

Phenolic compounds are the major class among the antioxidant agents, which are also considered as a major group of medicinal plant free radical scavengers. In the present study, we found that the TAA contains higher concentration of polyphenols and flavonoids (43\% and $1.1 \%$, respectively). However, Mety and Mathad ${ }^{28}$ have observed quite low concentrations of phenolic contents in methanolic and ethanolic extracts of $T$. arjuna bark when compared with the present results. Reactive oxygen species (ROS) such as hydroxyl radical $(\bullet \mathrm{OH})$, superoxide $\left(\mathrm{O}_{2}-\bullet\right)$, hydrogen peroxide $\left(\mathrm{H}_{2} \mathrm{O}_{2}\right)$ and reactive nitrogen species (RNS) like peroxynitrite (ONOO-), nitric oxide (NO•) and other radicals are the major sources of oxidative stress in cells, which can damage lipids, proteins and DNA. ${ }^{29}$ Hence, prevention of oxidative stress is a significant property of any medicinal plant or phytochemical for the management of stress related disorders. In the present study, all the arjuna fractions showed free radical scavenging activities against DPPH, ABTS, •OH, NO•, FRAP, metal chelation and reducing power. Moreover, TAE inhibited maximum free radicals and then followed by TAA and TAB. We speculate that arjuna extracts protect against oxidative stress-induced damage because of its high total phenolic content, free radical scavenging activity, DNA protection activity as well as its ability to prevent AAPH induced protein damage. Previous studies on experimental animal models ${ }^{30}$ also suggest that the T. arjuna alcoholic extract may help in altering the levels of cytochrome P-450 and other antioxidant enzymes like SOD, CAT, GST and GSH in different organs. The exogenous antioxidants from $T$. arjuna extracts may act directly or indirectly with the internal antioxidant system for synergistic effects to protect several diseases linked to free radicals such as, coronary heart diseases, neurodisorders and other stress related disorders.

\section{Conclusion}

In the present study, alcoholic extract of $T$. arjuna bark and its extracts were evaluated for DNA protection, protein oxidation and free radical scavenging activity. The results of the present research work leads to the conclusion that $T$. arjuna extracts (TAE, TAD, TAE, TAB and TAW) have significant antioxidant activity and potential to prevent protein oxidation, DNA damage protection (by pBR322 DNA and SCGE assay). The potent antioxidative activity and DNA protection ability of $T$. arjuna bark extracts may be endorsed with phenolic/flavonoid compounds. Moreover, there was a significant correlation was observed between free radical scavenging activity, in vitro DNA damage activity and the total phenolic/flavonoid content. Further isolation and characterizations of these extracts is in progress so as to identify the specific antioxidative/genoprotective compounds.

\section{Conflicts of interest}

All authors have none to declare.

\section{Acknowledgment}

Authors are thankful to Director, DFRL, Mysore for his kind support.

\section{References}

1. Karthikeyan K, Saralabai BR, Gauthaman K, Sathish KS, Devaraj NS. Cardioprotective effect of the alcoholic extract of Terminalia arjuna bark in an in vivo model of myocardial ischemic reperfusion injury. Life Sci. 2003;73: 2727-2739.

2. Kumar DS, Prabhakar YS. On the ethnomedical significance of the Arjun tree, Terminalia arjuna (Roxb.) Wight and Arnot. J Ethnopharmacol. 1987;20: 173-190.

3. Ram A, Lauria P, Gupta R, Kumar P, Sharma VN. Hypocholesterolaemic effects of Terminalia arjuna tree bark. J Ethnopharmacol. 1997;55:165-169.

4. Singh DV, Gupta MM, Santha Kumar TR, Saikia D, Khanuja SPS. Antibacterial principles from the bark of Terminalia arjuna. Curr Science. 2008;94:27-29.

5. Bachaya HA, Iqbal Z, Khan MN, Jabbar A, Gilani AH, Din IU. In vitro and In vivo anthelmintic activity of Terminalia arjuna bark. Int J Agri Bio. 2009;11:273-278.

6. Row LR, Murty PS, Subbarao GSR, Sastry CSP, Rao KVJ. Chemical examination of Terminalia species: part XII - isolation and structure determination of arjunic acid, a new trihydroxytriterpene carboxylic acid from the Terminalia arjuna bark. Ind J Chem. 1970;8:716-721.

7. Honda T, Murae T, Tsuyuki T, Takahashi T. The structure of arjungen: a new sapogenin from Terminalia arjuna. Chem Pharm Bull. 1976;24:178-180.

8. Anjaneyulu ASR, Prasad AVR. Chemical examination of the roots of Terminalia arjuna (Roxb) Wight and Arnot. Phytochemistry. 1982;21:2057-2060.

9. Ali A, Kaur G, Hamid H, et al. Terminoside A, a newtriterpine glycoside from the bark of Terminalia arjuna inhibits nitric oxide production in murine macrophages. J Asian Nat Prod Res. 2003;5:137-142.

10. Sharma PN, Shoeb PN, Kapil RS, Popli SP. Arjunolone-a new flavone from stem bark of Terminalia arjuna. Ind J Chem. 1982;21B:263-264.

11. Lin TC, Chien SC, Chen HF, Hsu FL. Tannins and related compounds from Combretaceae plants. Chin Pharm J. 2001;52:1-26.

12. Tiwari AK, Antioxidants New. - generation therapeutic base for treatment of polygenic disorders. Curr Sci. 2004;86:1092-1100.

13. Lee JC, Kim HR, Kim T, Jang YS. Antioxidant property of an ethanol extract of the stem of Opuntia ficus-indica Var. Saboten. J Agri Food Chem. 2002;175: 184-191.

14. Sing NP, Mccoy MT, Tice RR, Schneider EL. Simple technique for qunatitation of low level of DNA damage in individual cells. Exp Cell Res. 1988;175:184-191.

15. Kwon HY, Choi SY, Won MH, Kang TC, Kang JH. Oxidative modification and inactivation of $\mathrm{Cu}, \mathrm{Zn}$ - superoxide dismutase by 2,2'azobis (2-amidinopropane) dihydrochloride. Biochem Biophys Acta. 2000;1543:69-76.

16. Slinkard K, Singleton VL. Total phenol analyses: automation and comparison with manual methods. Am J Enology Viticulture. 1977;28:49-55.

17. Ordon E, Gomez AAL, Vattuone JD, Isla MI. Antioxidant activities of Sechium edule [Jacq.] Swart extracts. Food Chem. 2006;97:452-458.

18. Shimada K, Fujikawa K, Nakamura T. Antioxidative properties of xanthone on the autooxidation of soyabean in cyclodextrin emulsion. J Agri Food Chem. 1992;40:945-948.

19. Halliwell B, Gutteridge JMC. Free Radicals in Biology and Medicine. Oxford: Oxford University Press; 1999.

20. Re R, Pellegrini N, Proteggente A, Pannala A, Yang M, Rice-Evans C. Antioxidant activity applying an improved ABTS radical cation decolorization assay. Free Rad Bio Med. 1999;26:231-237.

21. Ebrahimzadeh MA, Ehsanifar S, Eslami B. Sambucus ebulus elburensis fruits: a good source for antioxidants. Pharmacog Mag. 2009;4:213-218.

22. Benzie IFF, Strain JJ. The ferric reducing ability of plasma (FRAP) as a measure of "antioxidant power": the FRAP assay. Anal Biochem. 1996;239:70-76.

23. Yen GH, Chen HY. Antioxidant activity of various tea extracts in relation to their antimutagenicity. J Agri Food Chem. 1995;43:27-32.

24. Voellmy R. Sensing and Responding to Stress. In: Feige U, Morimoto RI, Yahara I, Polla BS, eds. Stress-inducible Cellular Responses. Basel: Birkhaeuser Verlag Press; 1996:121-137.

25. Mastaloudis A, Yu TW, O’Donnell RP, Frei B, Dashwood RH, Traber MG. Endurance exercise results in DNA damage as detected by the comet assay. Free Rad Bio Med. 2004;36:966-975.

26. Harsha SN, Anilakumar KR. In vitro free radical scavenging and DNA damage protective property of Coriandrum sativum L. leaves extracts. J Food Sci Technol; 2012;. http://dx.doi.org/10.1007/S13197-012-0648-5.

27. Sivalokanathan S, Vijayababu MR, Balasubramanian MP. Effects of Terminalia arjuna bark extract on apoptosis of human hepatoma cell line HepG2. World J Gastroenterol. 2006;12:1018-1024.

28. Mety SS, Mathad P. Antioxidative and free radical scavenging activities of Terminalia species. Int Res J Biotechnol. 2011;2:119-127.

29. Berlett BS, Stadtman ER. Protein oxidation in aging, disease, and oxidative stress. J Bio Chem. 1997;272:20313-20316.

30. Manna P, Sinha M, Sil PC. Aqueous extract of Terminalia arjuna prevents carbon tetrachloride induced hepatic and renal disorders. BMC Compl Alter Med. 2006;6:1-10 